\title{
Rumah Sakit Paru \\ Dengan Pendekatan Healing EnVIronment Di KABUPATEN SRAGEN
}

\author{
Rachel Greaty Gracia, Sri Yuliani, Dyah S. Pradnya P. \\ Program Studi Arsitektur \\ Fakultas Teknik \\ Universitas Sebelas Maret Surakarta \\ Email : rachelgracia93@gmail.com
}

\begin{abstract}
Pulmonary Hospital Design with healing environment approach in Sragen is motivated by the increase in cases of lung disease in Sragen caused by viruses, bacteria, unhealthy lifestyle, and declining air quality. However, Sragen doesn't have yet a health facility that specialized in pulmonary and respiratory diseases, so the aim of this plan is to create a health facility in Sragen which is form Pulmonary Hospital. Design issue is how to apply the concept of healing environment on the elements of space that can reduce the impact of fear for the patient and landscape arrangement to be one of healing therapy. The method used is architectural design method. Pulmonary Hospital design is the result of the analysis of space requirements, the processing site, the order of mass, mass composition, arrangement of space, and processing landscape by using a healing environment to help the recovery of the patient physically and psychologically.
\end{abstract}

Keywords: Healing Environment, Health Facility, Lung and Respiratory Disease, Pulmonary Hospital

\section{PENDAHULUAN}

Penyakit yang berkaitan dengan organ paru dan pernapasan termasuk penyakit yang menyebabkan kematian terbanyak di Indonesia. Faktor penyebab dari penyakit tersebut adalah virus, bakteri, merokok, gaya hidup kurang sehat, dan kualitas udara yang semakin memburuk. Salah satu kota dengan proporsi penderita paru terbanyak adalah di Kabupaten Sragen. Penyakit paru-paru terkhusus TBC di Kabupaten Sragen pada akhir tahun 2013 memiliki jumlah penderita sebanyak 545 jiwa (Sragen dalam Angka, 2014).

Pasien penyakit paru membutuhkan penanganan khusus dan intensif karena penyakit yang menyerang organ paru membutuhkan waktu yang panjang untuk pemulihan. Selain waktu yang panjang pasien paru-paru juga harus ditempatkan secara khusus dengan sistem ventilasi baik, kualitas udara, dan jauh dari pasien penyakit lain sehingga tidak terjadi penularan penyakit dari atau ke pasien lain. Dengan dasar tersebut maka dibutuhkan sebuah tempat pengobatan dan perawatan khusus penyakit paru supaya proses pengobatan, perawatan, dan pemulihan kesehatan pasien lebih maksimal.

Kondisi eksisting fasilitas kesehatan Kabupaten Sragen terdiri dari rumah sakit sejumlah 10 buah dan Puskesmas sejumlah 86 buah (Sragen dalam Angka 2014). Saat ini, kondisi fasilitas kesehatan yang tersedia belum terdapat fasilitas berupa rumah sakit yang secara khusus menangani penyakit paru.

Pertimbangan pembangunan rumah sakit di Sragen juga didukung oleh kondisi lahan yang cukup luas dengan persentase penggunaan lahan bukan pertanian sebesar $28,90 \%$ (Sragen dalam Angka, 2014), sehingga masih sangat berpotensi untuk dikembangkan fasilitas tersebut. Adapun keberadaan bangunan rumah sakit paru yang berada di Kabupaten Sragen diharapkan mampu mengurangi angka penderita penyakit paru di Kabupaten Sragen.

Rumah sakit paru dirancang sebagai fasilitas kesehatan di Kabupaten Sragen yang menangani penyakit paru secara spesifik. Faktor pembeda dari rumah sakit lain adalah pada jenis pendekatan. Pada rumah sakit paru di Kabupaten Sragen menggunakan healing 
environment yang memiliki tiga pendekatan yaitu alam, indra, dan psikologis (Vidra Lidayana, 2013). Beberapa elemen desain yang digunakan adalah kebisingan, warna, tekstur, penghawaan, pencahayaan, dan healing garden. Pendekatan healing environment bertujuan untuk membuat lingkungan menjadi hijau dan juga menyesuaikan psikologis pasien sehingga mempercepat proses pemulihan.

\section{METODE}

Berdasarkan konsep perencanaan dan perancangan, rumah sakit paru yang direncanakan menerapkan pendekatan konsep healing environment dalam aspek kebisingan, bentuk ruang, warna, skala, tekstur, penghawaan, pencahayaan, dan healing garden.

Konsep healing environment yang diterapkan pada kebisingan adalah penggunaan vegetasi sebagai buffer kebisingan dan penempatan bangunan sesuai dengan zona.

Konsep healing environment yang digunakan pada warna dan tekstur yaitu menyesuaikan psikologis pasien sehingga menghasilkan tata ruang yang nyaman.

Konsep healing environment yang diterapkan pada pencahayaan dan penghawaan adalah penambahan vegetasi, pengolahan bukaan, shading, orientasi bangunan, dan desain yang menggunakan sistem cross ventilation. Penerapan konsep tersebut bertujuan untuk mendapatkan pencahayaan dan penghawaan alami dengan dasar pertimbangan garis edar matahari dan arah pergerakan angin.

Konsep healing environment pada rumah sakit paru yaitu penerapan healing garden yang menjadi upaya untuk membentuk suasana yang membantu proses pemulihan pasien. Beberapa elemen yang terdapat pada healing garden adalah elemen vegetasi, elemen air (kolam), dan elemen keras (bangku, lampu, dan lain-lain).

\section{ANALISIS}

\section{A. Analisis Peruangan}

Penulisan analisis kebutuhan ruang didasarkan pada kegiatan di rumah sakit paru seperti terlihat pada Tabel 1 .
Tabel 1.Kebutuhan Ruang

\begin{tabular}{|l|l|}
\hline \multicolumn{1}{|c|}{$\begin{array}{c}\text { KELOMPOK } \\
\text { KEGIATAN }\end{array}$} & \multicolumn{1}{c|}{ INSTALASI RUANG } \\
\hline Gawat Darurat & IGD \\
\hline Rawat Jalan & Instalasi Rawat Jalan \\
\hline Rawat Inap & Instalasi Rawat Inap, ICU \\
\hline Penunjang Medik & $\begin{array}{l}\text { Instalasi Bedah Medik, } \\
\text { Farmasi, Radiologi, } \\
\text { Laboratorium, Rehabilitasi } \\
\text { Medik }\end{array}$ \\
\hline $\begin{array}{l}\text { Penunjang Non } \\
\text { Medik }\end{array}$ & $\begin{array}{l}\text { Instalasi Rekam Medik, } \\
\text { Administrasi, Pusdiklat, } \\
\text { Konvensi dan TI }\end{array}$ \\
\hline Servis & $\begin{array}{l}\text { Instalasi Pemulasaraan } \\
\text { Jenazah, CSSD, Dapur dan } \\
\text { Gizi, Laundry, Sanitasi dan } \\
\text { IPAL, dan IPSRS }\end{array}$ \\
\hline
\end{tabular}

Sumber: Depkes RI, 2007

B. Analisis Lokasi

Lokasi yang direncanakan untuk rumah sakit paru sesuai dengan RTRW Kab. Sragen dan merupakan lokasi yang strategis.

1. Tujuan

Mendapatkan lokasi yang sesuai dengan kebutuhan rumah sakit paru.

2. Dasar Pertimbangan

Berada di kecamatan yang terdeteksi kasus penyakit paru terbanyak.

\section{Analisis Pencapaian}

Pencapaian ke dalam bangunan harus mudah diakses terutama dalam kondisi darurat, mudah dilihat dan memiliki sirkulasi yang aman.

1. Tujuan

Menentukan main entrance dan side entrance.

2. Dasar Pertimbangan

Entrance yang jelas, kemudahan akses, sirkulasi tapak yang aksesibel, potensi jalan, tingkat keamanan.

3. Proses Analisis

Main Entrance (ME) mudah dijangkau dan terlihat dengan jelas. Terdapat dua titik $\mathrm{ME}$ 
sebagai akses masuk dan keluar kendaraan umum.

Side Entrance (SE) tidak mengganggu keberadaan ME. Terdapat dua titik SE sebagai akses masuk dan keluar kegiatan servis.

Pola pencapaian rumah sakit paru dapat dilihat pada Gambar 1.

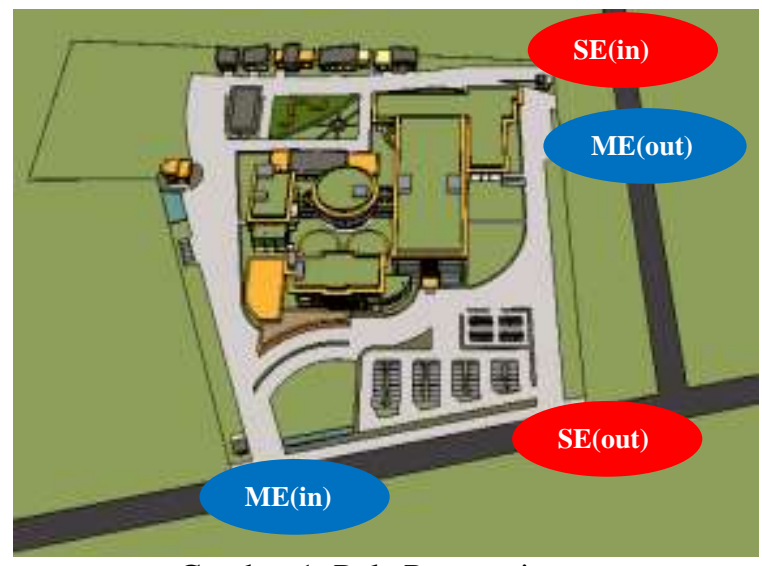

Gambar 1. Pola Pencapaian

D. Analisis Pemintakatan

Pemintakatan berdasarkan sifat kegiatan dan tingkat kenyamanan suara yang dibutuhkan sebagai pedoman dalam penataan peruangan.

1. Tujuan

Mendapatkan zonning yang tepat untuk masing-masing kelompok kegiatan.

2. Dasar Pertimbangan

Kedekatan hubungan antar kelompok kegiatan dan tingkat kenyamanan suara yang dibutuhkan.

3. Proses Analisis

Persyaratan ruang berdasarkan kelompok kegiatan dan kebutuhan ketenangan. Pembagian zona pada rumah sakit terdiri dari zona publik, zona semi publik, zona privat, dan zona servis.

Konsep healing environment diterapkan pada penempatan healing garden yang bisa dinikmati semua pengguna rumah sakit paru. Analisis pemintakatan rumah sakit paru dapat dilihat pada Tabel 2.
Tabel 2. Analisis Pemintakatan

\begin{tabular}{|l|l|l|}
\hline ZONNING & \multicolumn{1}{|c|}{ RUANG } & $\begin{array}{c}\text { TINGKAT } \\
\text { KEBISING } \\
\text {-AN }\end{array}$ \\
\hline Publik & $\begin{array}{l}\text { IGD, Poliklinik, } \\
\text { Bedah Medik, } \\
\text { Farmasi, } \\
\text { Radiologi, } \\
\text { Laboratorium, } \\
\text { Rehabilitasi } \\
\text { Medik, Rekam } \\
\text { Medik, }\end{array}$ & \\
\hline $\begin{array}{l}\text { Semi } \\
\text { publik }\end{array}$ & $\begin{array}{l}\text { ICU dan } \\
\text { Administrasi }\end{array}$ & \\
\hline Privat & Rawat Inap & Tinggi \\
\hline Servis & $\begin{array}{l}\text { Pemulasaraan } \\
\text { Jenazah, CSSD, }\end{array}$ & Rendah \\
& $\begin{array}{l}\text { Dapur dan Gizi, } \\
\text { Laundry, } \\
\text { Sanitasi dan } \\
\text { IPAL, IPSRS }\end{array}$ & \\
\hline
\end{tabular}

E. Analisis Gubahan Massa dan Tampilan Bangunan

1. Analisis Gubahan Massa

Analisis mengenai bentuk untuk menentukan gubahan massa yang sesuai untuk rumah sakit paru. Gubahan massa mengambil bentuk persegi dan lingkaran agar bangunan bersifat dinamis dan juga efektif. Dengan bentuk yang dinamis menjadikan rumah sakit berkarakter homey dan menyenangkan seperti pada Gambar 2.

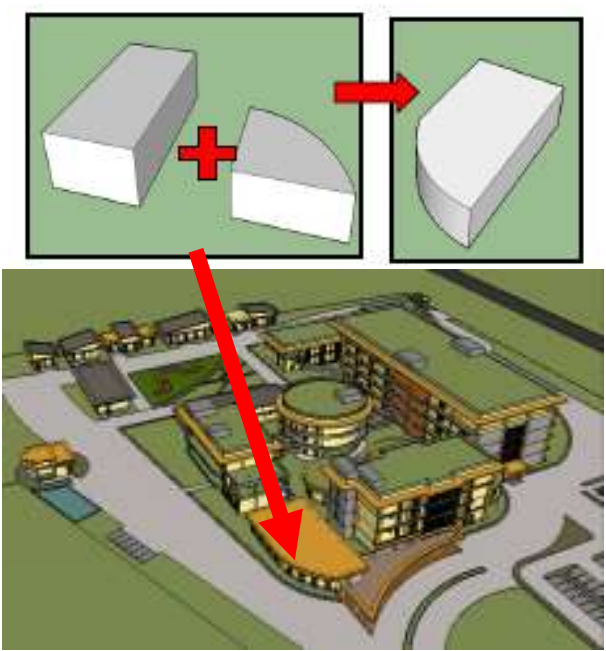

Gambar 2. Gubahan Massa 
2. Analisis Tampilan Bangunan

Penerapan konsep healing environment pada tampilan bangunan yaitu adanya pengolahan vegetasi agar menghasilkan udara yang sejuk dan teduh. Bentuk pengolahan vegetasi yaitu sebagai berikut.

a. Penempatan healing garden sebagai view sekaligus terapi psikologis seperti pada Gambar 3.

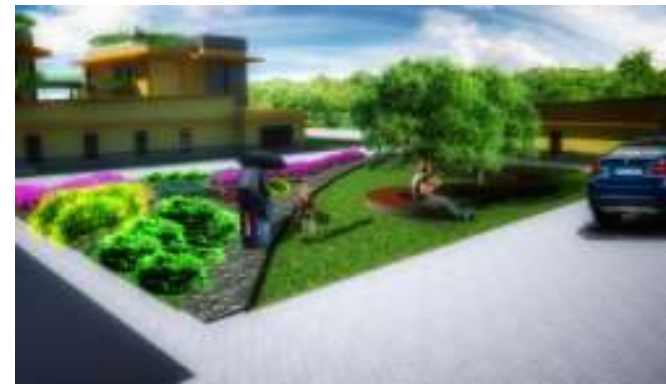

Gambar 3. Healing Garden

b. Pemanfaatan taman vertikal pada setiap balkon

c. Pemanfaatan roof garden pada ruang rawat inap dan ruang bedah medik seperti terlihat pada Gambar 4.

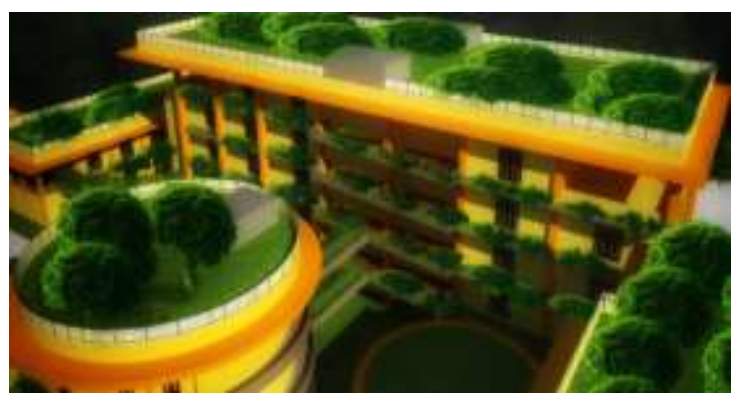

Gambar 4. Taman Vertikal dan Roof Garden

F. Analisis Elemen Ruang

Elemen ruang dianalisis sebagai bentuk terapi psikologis bagi pengguna rumah sakit paru.

1. Tujuan

Menghasilkan suasana nyaman bagi pengguna dengan memanfaatkan potensi alam dan terapi psikologis.

2. Dasar Pertimbangan
Pertimbangan dalam analisis elemen ruang yaitu pencahayaan dan penghawaan alami serta konsep healing environment.

3. Proses Analisis

Konsep healing environment yang digunakan yaitu warna dan tekstur yang menyesuaikan psikologis pasien sehingga menghasilkan tata ruang yang nyaman.

Salah satu ruangan inti yang memerlukan perhatian khusus adalah ruang rawat inap. Pengolahan tata ruang pada ruangan ini bertujuan untuk mengkomunikasikan pasien dengan lingkungan. Unsur alam dapat dinikmati secara visual dan penciuman dapat mengurangi stres dan kepenatan.

Pengolahan tata ruang rawat inap anak dengan pendekatan healing environment dapat dilihat pada Gambar 5.

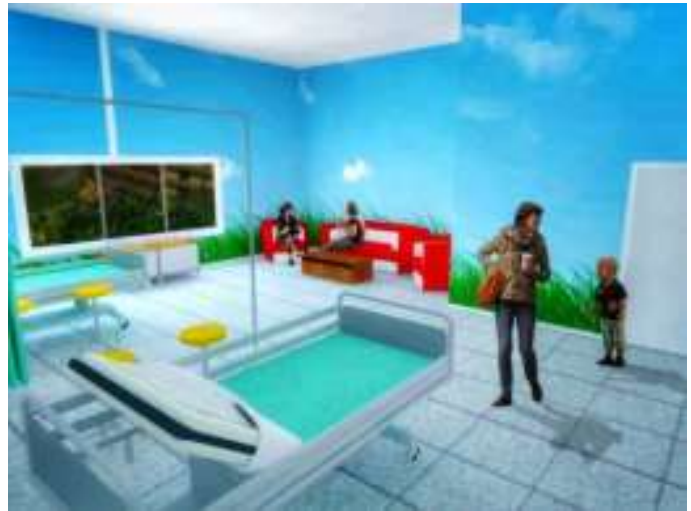

Gambar 5. Tata Ruang Rawat Inap Anak

G. Analisis Lansekap

Penerapan konsep healing environment pada lansekap untuk menghasilkan kenyamanan bagi pengguna rumah sakit paru.

1. Tujuan

Mendapatkan desain taman yang berfungsi sebagai terapi pasien, tata ruang hijau, dan barrier terhadap polusi serta kebisingan.

2. Dasar Pertimbangan

Pertimbangan dalam analisis lansekap yaitu sirkulasi yang nyaman, jenis dan peletakan 
vegetasi, kenyamanan dan keindahan visual serta konsep healing environment.

3. Proses Analisis

Konsep healing environment pada rumah sakit paru yaitu penerapan healing garden untuk membentuk suasana yang membantu proses pemulihan pasien. Penerapan elemen pembentuk lansekap sebagai berikut.

a. Elemen Vegetasi (Softscape)

Pemilihan jenis vegetasi yang berfungsi sebagai view untuk meredakan stres, buffer terhadap panas dan polusi, serta sebagai aromaterapi.

b. Elemen Air

Penggunaan kolam berfungsi untuk meredam panas dan sebagai terapi psikologi.

c. Elemen Keras (Hardscape)

Dimanfaatkan sebagai jalur pedestrian, area tangkapan air hujan, dan terapi.

H. Analisis Struktur dan Utilitas

1. Analisis Struktur

Bertujuan mendapatkan desain yang kuat untuk bangunan bertingkat rendah. Selain itu struktur juga mempertimbangkan peraturan bangunan setempat.

a. Sub Structure

Berdasarkan keamanan, kekokohan terhadap beban, dan efektivitas pekerjaan serta ketinggian bangunan maka terdapat beberapa pilihan pondasi yang akan diterapkan. Pondasi batu kali dipakai untuk bangunan 1 lantai. Pondasi foot plate dipakai untuk bangunan dengan ketinggian 2-3 lantai. Pondasi tiang pancang dipakai untuk bangunan dengan ketinggian 4-5 lantai.

b. Super Structure

Berdasarkan ketinggian lantai, dimensi ruang, kekuatan, dan efektivitas struktur maka struktur yang digunakan sistem rangka (rigid frame).

c. Upper Structure

Berdasarkan pertimbangan dan karakteristik masing- masing upper structure, maka sistem yang dipilih adalah stuktur komposit (composit structure) yang merupakan kombinasi baja struktural dengan beton bertulang.

2. Analisis Utilitas

Utilitas merupakan bagian penting dalam perancangan rumah sakit. Berikut analisis mengenai sistem air bersih dan pengolahan limbah.

a. Sistem Air Bersih

Terdapat alternatif sistem distribusi yaitu up feed distribution dan down feed distribution. Dari alternatif tersebut dipilih sistem down feed distribution karena tekanan tidak terlalu besar, cara kerja dan perawatan tangki sangat sederhana.

Sistem air bersih rumah sakit paru dapat dilihat pada Gambar 7.

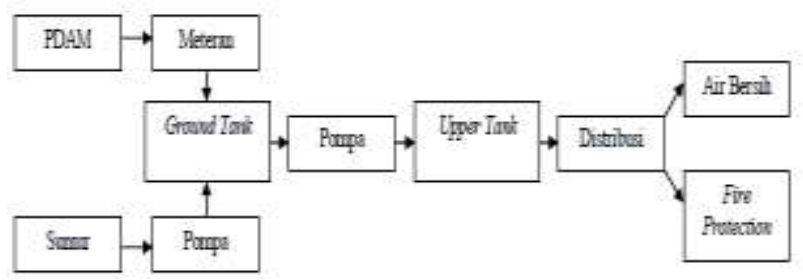

Gambar 6. Sistem Air Bersih

b. Sistem Pengolahan Air Limbah Limbah dibedakan menjadi limbah padat dan limbah cair. Pengolahan standar sesuai dengan peraturan Departemen Kesehatan RI.

Pengolahan limbah padat dan cair dapat dilihat pada Tabel 3. dan Gambar 7.

Tabel 3. Pengolahan Limbah Padat

\begin{tabular}{|c|l|}
\hline Kategori & \multicolumn{1}{c|}{ Pengolahan } \\
\hline Radioaktif & $\begin{array}{l}\text { Diserahkan ke BATAN } \\
\text { (Badan Tenaga Nuklir }\end{array}$ \\
\hline
\end{tabular}




\begin{tabular}{|c|c|}
\hline & Nasional) \\
\hline $\begin{array}{l}\text { Sangat } \\
\text { infeksius } \\
\text { (dari } \\
\text { laboratorium) }\end{array}$ & $\begin{array}{l}\text { Dibakar di insinerator } \\
\text { (Benda tajam dihancurkan } \\
\text { dengan neddle crusher } \\
\text { terlebih dahulu) }\end{array}$ \\
\hline $\begin{array}{l}\text { Infeksius, } \\
\text { patologi, dan } \\
\text { anatomi }\end{array}$ & $\begin{array}{l}\text { Dibakar di insinerator } \\
\text { (Benda tajam dihancurkan } \\
\text { dengan neddle crusher } \\
\text { terlebih dahulu) }\end{array}$ \\
\hline Sitotoksik & $\begin{array}{l}\text { Dikembalikan ke } \\
\text { distributor atau dilakukan } \\
\text { insinerator sekaligus } \\
\text { degradasi kimia }\end{array}$ \\
\hline $\begin{array}{l}\text { Kimia dan } \\
\text { famasi }\end{array}$ & $\begin{array}{l}\text { Dikembalikan ke } \\
\text { distributor atau dilakukan } \\
\text { insinerator sekaligus } \\
\text { degradasi kimia }\end{array}$ \\
\hline Umum & $\begin{array}{l}\text { Diletakkan pada Tempat } \\
\text { Pembuangan Sementara } \\
\text { (TPS) }\end{array}$ \\
\hline
\end{tabular}

Sumber: Depkes RI, 2007

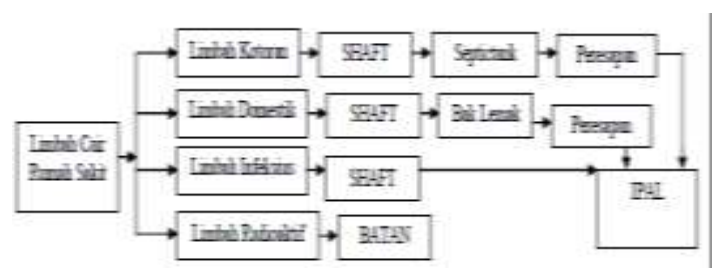

Gambar 7. Analisis Limbah Cair Sumber: Depkes RI, 2007

\section{KESIMPULAN (KONSEP DESAIN)}

Konsep rancangan rumah sakit paru berpijak pada pendekatan healing environment sehingga menghasilkan desain yang nyaman sekaligus terapi psikologis bagi pengguna rumah sakit. Selain itu, pengolahan lansekap pada bangunan rumah sakit paru tidak hanya berfungsi sebagai peneduh dan barrier saja, tetapi juga sebagai terapi sehingga mendukung mempercepat pemulihan pasien.

Dari hasil analisis serta hasil korelasi dari beberapa data di atas, maka diperoleh hasil berupa rancangan Rumah Sakit Paru di Kabupaten Sragen seperti terlihat pada Gambar 9. dan Lampiran 1. yang menunjukkan fasad. Pada Gambar 10. dan Lampiran 2. menunjukkan tata ruang dengan data bangunan sebagai berikut.
Bangunan
: Rumah Sakit Paru
Lokasi
: Jl. Maospati-Surakarta,
Kecamatan Sragen

Luas Lahan $\quad: 40.047,5 \mathrm{~m}^{2}$

Luas Bangunan : $20.000 \mathrm{~m}^{2}$

Daya Tampung : 200 pasien

Kegiatan : Pelayanan kesehatan paru

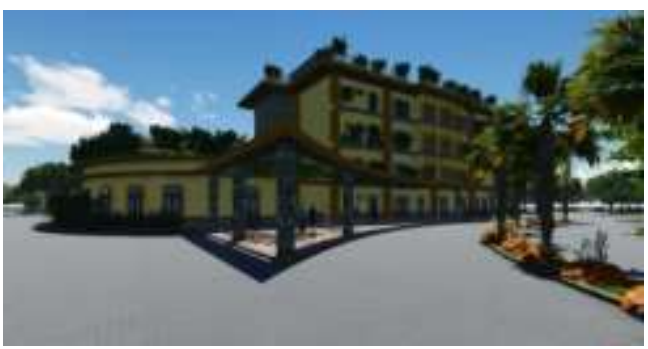

Gambar 8. Eksterior

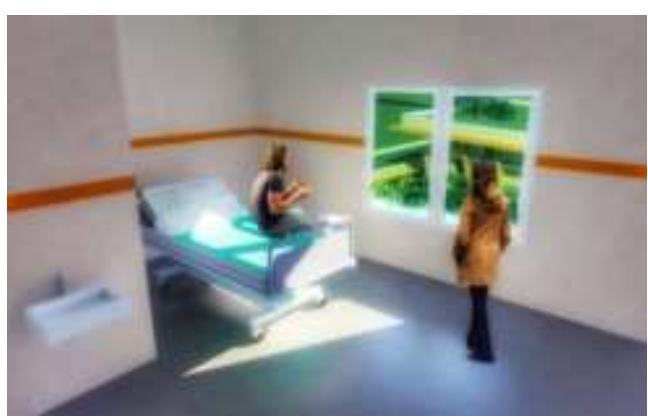

Gambar 9. Interior

\section{REFERENSI}

Sekretariat Jenderal, Departemen Kesehatan RI. 2007. Pedoman Teknis Sarana dan Prasarana Rumah Sakit Kelas C.

Sragen dalam angka. 2014.

Vidra Lidayana, M Ridha Alhamdani,

Valentinus Pebriano. 2013. Konsep dan

Aplikasi Healing Environment dalam Fasilitas Rumah Sakit. Jurnal Teknik Sipil, Vol. 13, No. 2 
LAMPIRAN

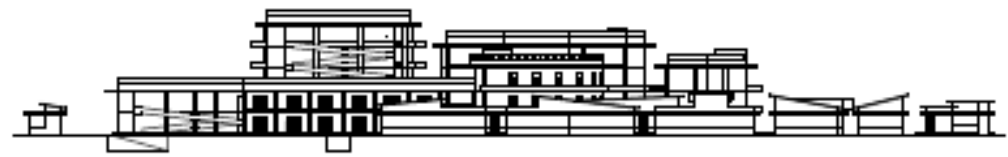

TAMPAK DEPAN

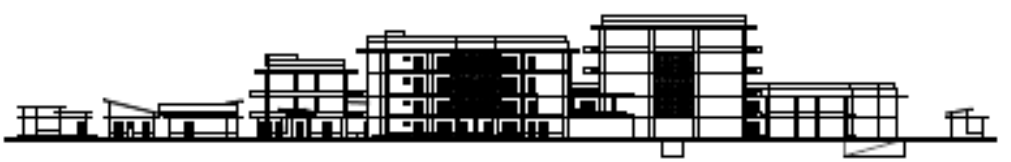

TANPAK BELAKANG

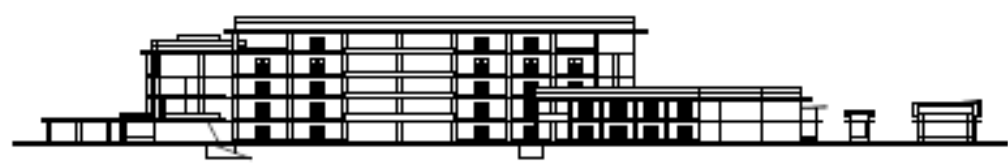

TAMPAK BAMFING

Lampiran 1. Tampak Rumah Sakit Paru

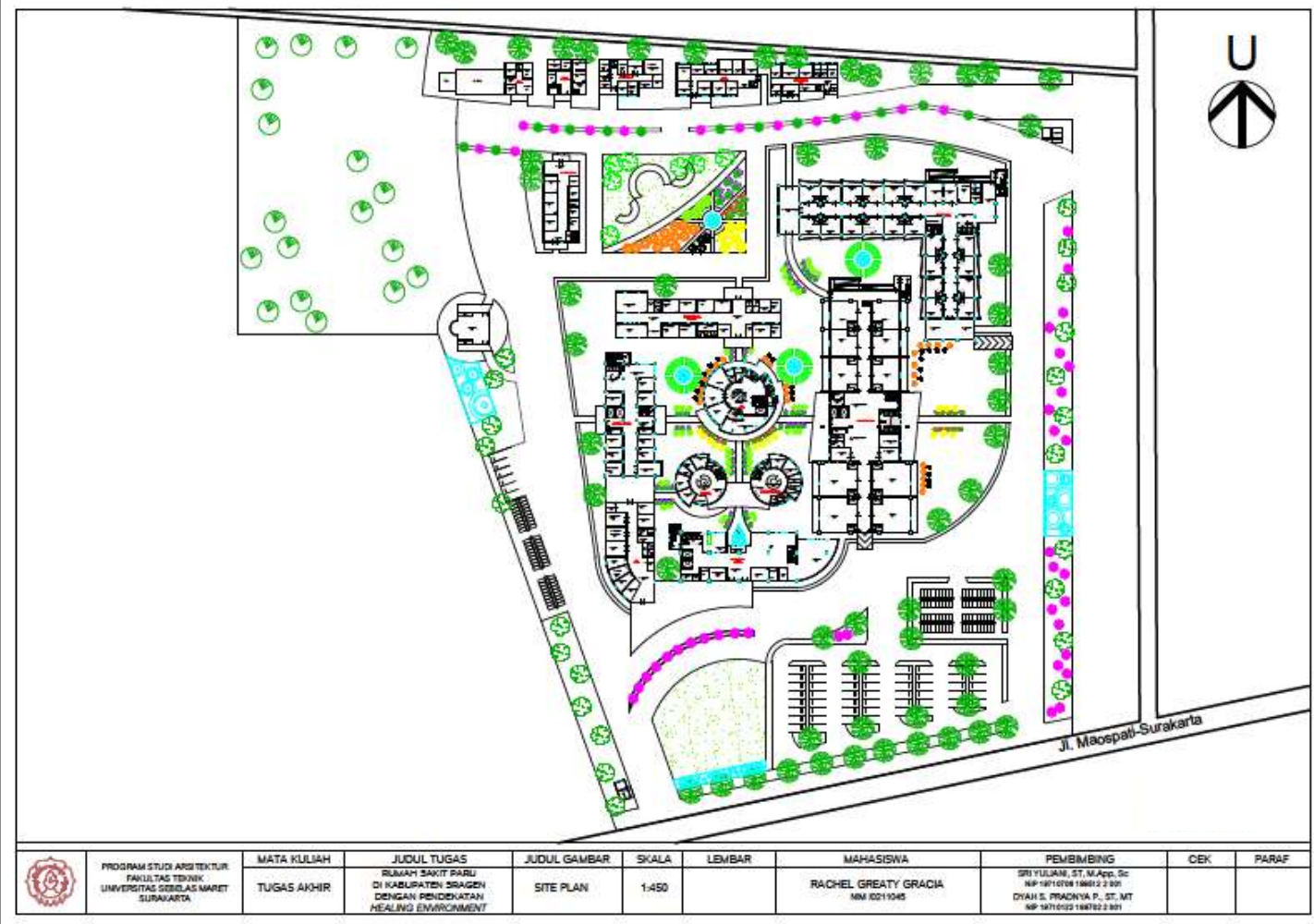

Lampiran 2. Rencana Tapak 